\title{
SNOW WETNESS MEASUREMENT BY FLUORESGENT DYE DILUTION
}

\author{
By Robert E. Davis and JefF Dozier \\ (Department of Geography, University of California, Santa Barbara, California 93106, U.S.A.)
}

Abstract. The fluorescent dye dilution method for determining the liquid-water content in snow is based on measuring the concentration change of a solution when it is mixed with snow. Samples for analysis can be obtained rapidly and reliably, and, unlike calorimetric or equilibriumtemperature methods, field use requires no on-site data analysis.

RÉsumé. Mesure de la teneur en eau de la neige par changement des couleurs de fluorescence dans les dilutions. La méthode des dilutions à variation de couleur de fluorescence pour la détermination de la teneur en eau liquide dans la neige est basée sur la mesure de la variation de la concentration lors de son mélange avec la neige. Des échantillons pour l'analyse peuvent être obtenus

\section{INTRODUCTION}

The change in concentration when an aqueous solution is mixed with wet snow provides a basis for measuring the liquid-phase fraction of snow. One method of measuring concentration changes uses a saline solution, which, when mixed in a dewar with a snow sample, produces a temperature depression in the mixture. The resulting solution concentration is determined from the equilibrium temperature, and the heat balance is calculated to adjust the result because of the liquid water produced by the brine and by the heat from the dewar. This method was proposed by Bader $(1948,1950)$ and recently improved by Morris (1981) who tested it in the field. Colbeck (1978) reviewed various techniques for measuring the liquidwater content of snow, and concluded that Bader's method should be accurate, as long as the concentration of the original saline solution is accurately known.

Other techniques can be used to measure concentration changes directly, and considerable practical advantage is gained if solution samples can be extracted and stored for later analysis, eliminating the need for on-site data analysis. LaChapelle and Perla (unpublished) proposed the use of a spectrophotometer to determine the dilution of a dye solution.

In the method described in this paper, we use a fluorometer. A fluorescent dye solution at $0^{\circ} \mathrm{C}$ is added to a snow sample and a small amount is extracted after thorough mixing. If no phase change occurs, the change in concentration corresponds to the amount the dye was diluted by the liquid water in the snow sample. A favorable attribute of fluorescent dyes, in comparison to saline solutions, is that accurate measurement is possible with concentrations that produce negligible freezing-point depression.

\section{THEORY}

A known mass of solution $m_{1}$ at concentration $C_{1}$ is added to a known mass of snow $m_{s}$ containing mass $m_{j}$ of $i c e$ and mass $m_{w}$ of liquid water. After mixing, the sample has 1 iquid water content $m_{1}+m_{w}$. The concentration $C_{2}$ of the mixture of solution and snow liquid water is

$$
c_{2}=c_{1} \frac{m_{1}}{m_{1}+m_{w}} \text {. }
$$

rapidement et de façon fiable, et, contrairement aux méthodes calorimétriques ou d'équilibre de température, les prélèvements ne nécessitent pas d'analyses in situ.

Zusammenfassung. Messung der Schneefeuchte mit fluoreszierenden Farblösungen. Die Methode der fluoreszierenden Farblösung zur Bestimmung des Wassergehaltes im Schnee beruht auf der Messung der Konzentrationsänderung einer mit Schnee vermischten Lösung. Proben für eine Analyse können schnell und zuverlässig gewonnen werden; im Gegensatz zu kalorimetrischen oder Temperaturgleichgewichts-Methoden erfordert der Gebrauch im Feld keine Analyse am Beobachtungsort.

At low concentrations, less than about 1.5 p.p.m., fluorescent intensity is directly proportional to solution concentration. At higher concentrations the dye solution may exhibit quenching or internal absorption so that the intensity-concentration relationship becomes nonlinear, and may not be monotonic. Once linearity is determined with a calibration curve (intensity versus concentration) the ratio of initial fluorescent intensity $I_{1}$ to the final intensity $I_{2}$

yields the ratio of the concentrations and the inverse ratio of the masses of solution:

$$
\frac{I_{1}}{I_{2}}=\frac{C_{1}}{C_{2}}=\frac{m_{1}+m_{W}}{m_{1}} .
$$

The mass fraction of snow liquid-water content is

$$
x_{W}=\frac{m_{W}}{m_{S}}=\frac{\left(I_{1}-I_{2}\right) m_{1}}{I_{2} \rho_{W} V_{S}} .
$$

The volume fraction $\theta_{w}$ of liquid water in the snow sample with volume $V_{S}$ is

$$
\theta_{W}=\frac{x_{W} m_{S}}{\rho_{W} V_{S}}=\frac{\left(I_{1}-I_{2}\right) m_{1}}{I_{2} \rho_{W} V_{S}}
$$

where $\rho_{w}$ is the density of water.

The freezing-point depression can be calculated for ideal dilute solutions (Daniels and Alberty, 1975 , p. 130) as

$$
\Delta T_{f} \approx K_{f} M
$$

where $K_{f}$ is $1.86 \mathrm{deg} \mathrm{mol}{ }^{-1}$ for water and $M$ is the molal concentration (moles solute per kilogram of solvent). A dye solution concentration of 1 p.p.m., produces a freezing point depression of c. $4 \times 10^{-6} \mathrm{deg}$. METHOD

Rhodamine WT is the dye used in this study because it has a low minimum detectability, low photochemical decay, and low cost (Smart and Laidlaw, 1977). It is purchased as a concentrated solution, specified as $20 \%$ by weight. A dilute solution (1 p.p.m.) is pre- 
pared in the laboratory and then carefully measured into small vials, $100 \mathrm{~g}$ each. Some of the solution is saved for the measurement of initial fluorescent intensity.

A $500 \mathrm{~cm}^{3}$ snow sample is removed from the snow surface or a pit wall using a coring tool and a steel spatula, which have been kept at snow temperature by storage in the adjacent snow. The sample is weighed with a triple-beam balance, then put into the mixing container, a thin-wall stainless-steel wide-mouthed bottle that is immersed in an ice bath. The container is covered with an insulating lid between uses, and the mixture is stirred with a rod through the lid when the air temperature is warm. The ice bath can be maintained in a standard ice chest.

The pre-measured dye solution $\left(m_{1}=100 \mathrm{~g}\right)$ is brought to $0^{\circ} \mathrm{C}$ in the field, by placing the vials in the ice bath some minutes before measurement. The contents of a vial are poured over the snow sample, and the mixture is shaken and stirred for about 30 s. A small amount of liquid $(c .5 \mathrm{ml})$ is extracted with a squeeze bulb and a pipette fitted with a fine screen on the end to separate the liquid from the ice grains. The sample is stored in a small bottle for later analysis.

A Turner Associates filter fluorometer, Model 110, was used for the data analysis. The filters used followed the recommendations of Smart and Laidlaw (1979), the primary using Corning 1-60 with Wratten 61 and the secondary Corning 4-97 with Corning 3-66. Possibly lower concentrations of rhodamine WT could be used if the fluorometer were more sensitive. The fluorescent intensity measurements require $3.5 \mathrm{ml}$ of solution. Each sample is measured alternately with the standard.

\section{ERRORS}

Worst-case absolute errors in the measurement of the mass and volume liquid phase fraction are

$$
\begin{aligned}
& \left|\Delta x_{w}\right|<\frac{1}{m_{S}}\left\{2\left(m_{w}+m_{1}\right) E(I)+m_{w}\left[E\left(m_{S}\right)+E\left(m_{1}\right)\right]\right\}, \\
& \left|\Delta \theta_{w}\right|<\frac{1}{\rho_{w} v_{S}}\left\{2\left(m_{w}+m_{1}\right) E(I)+m_{w}\left[E\left(V_{S}\right)+E\left(m_{2}\right)\right]\right\}
\end{aligned}
$$

where $E$ is the relative error, defined as

$$
E(z) \equiv \Delta z / z \text {. }
$$

Relative errors for the measurements of snow volume, snow mass, solution mass, and fluorescent intensity, with our apparatus, for snow densities between 250 and $650 \mathrm{~kg} \mathrm{~m}^{-3}$, are estimated at

$$
\begin{aligned}
& E\left(V_{S}\right)<0.01, E\left(m_{S}\right)<0.001, \\
& E\left(m_{1}\right)<0.001, E(I)<0.03 .
\end{aligned}
$$

Therefore

$$
\left|\Delta x_{w}\right|<0.025,\left|\Delta \theta_{w}\right|<0.013 \text {. }
$$

Errors in the liquid mass fraction $x_{W}$ and volume fraction $\theta_{w}$ are sensitive to $E(I)$, the relative error in the fluorescent intensity measurement. If $E(I)$ were reduced to 0.01 , errors in $x_{W}$ and $\theta_{W}$ reduce to

$$
\left|\Delta x_{w}\right|<0.008,\left|\Delta \theta_{w}\right|<0.004 \text {. }
$$

Another possible error source is inadequate mixing of the dye solution with the snow sample. The error in $\mathrm{x}_{\mathrm{w}}$ increases with the amount of solution added (Equation (6)), but if too little is added the resulting mixture is inhomogeneous. If too much is added, the dye dilution is too slight. Visual tests with concentrated dye solutions showed that 50-60 g are required to obtain adequate mixing.

\section{TESTS AND DISCUSSIONS}

The technique was tested in a variety of field and laboratory conditions. Comparisons with other techniques have not yet been made.

For laboratory trials, large volumes of snow, 0.1 to $0.25 \mathrm{~m}^{3}$ at densities from 350 to $650 \mathrm{~kg} \mathrm{~m}^{-3}$, were sieved into a specially designed cabinet, with ice baths in the side-walls surrounded by insulating foam and a $0.20 \mathrm{~m}$ layer of fine sand in the bottom to reduce the thickness of the saturated basal layer. The fluorescent dye dilution method consistently gave zero water content for dry frozen snow of varying densities, demonstrating that the mixing process itself causes no melting. The snow was then partially melted by radiation and allowed to drain; a metal pan collected melt water. Measurements of snow liquidwater content in samples of various densities at field capacity were found to be in good agreement with those published by Denoth and others (1979).

In field trials the method seems easy to use and requires little training. The time required for snow sample removal from a pit wall, mixing, and solution sample extraction is about $5 \mathrm{~min}$. Thus fluorescent dye solution appears to be a useful technique for the field measurement of snow wetness. Compared to alternatives, it is acceptably accurate, requires little field apparatus, uses only snow and water as a coolant, and is fast.

\section{ACKNOWLEDGEMENTS}

Dan Dawson of the University of California Sierra Nevada Aquatic Research Laboratory gave invaluable help. Ron Perla and Albert Rango made useful comments on an earlier draft of the manuscript. Funding was provided by NASA Grant NGT-803.

\section{REFERENCES}

Bader, H. 1948. Theory of non-calorimetric methods for the determination of the liquid water content of wet snow. Schweizerische Mineralogische und Petrographische Mitteilungen, Bd. 28, Ht. 2, p. 355-61.

Bader, H. 1950. Note on the liquid water content of wet snow. Journal of Glaciology, Vol. 1, No. 8, p. 466-67.

Colbeck, S.C. 1978. The difficulties of measuring the water saturation and porosity of snow. Journal of Glaciology, Vol. 20, No. 82, p. 189-201.

Daniels, F., and Alberty, R.A. 1975. Physical chemistry. Fourth edition. New York, John Wiley and Sons Inc.

Denoth, A. 1979. Study of water drainage from columns of snow. CRREL Report (Hanover, N.H.) 79-1.

LaChapelle, E.R., and Perla, R.I. Unpublished. Wet snow revisited. [Paper presented at International Snow Science Workshop, Bozeman, Montana, 1982.]

Morris, E.M. 1981. Field measurement of the 1 iquidwater content of snow. Journal of Glaciology, Vol. 27, No. 95, p. 175-78.

Smart, P.L., and Laidlaw, I.M.S. 1977. An evaluation of some fiuorescent dyes for water tracing. Water Resources Research, Vol. 13, No. 1, p. 15-33. 